\title{
HUBUNGAN PENGETAHUAN DAN DUKUNGAN SUAMI DENGAN PEMILIHAN ALAT KONTRASEPSI DALAM RAHIM (AKDR) PADA PASANGAN USIA SUBUR (PUS) DI KELURAHAN PURWOYOSO KECAMATAN NGALIYAN KOTA SEMARANG
}

\author{
KNOWLEDGE CONNECTION AND HUSBAND SUPPORT WITH ELECTORAL \\ CONTRACEPTION EQUIPMENT IN THE UTERUS(AKDR) \\ IN THE HIDDEN AGE (PUS) IN THE VILLAGE \\ PURWOYOSO DISTRICT NGALIYAN \\ SEMARANG CITY
}

\author{
Sri Mularsih ${ }^{1)}$ Laelatul Munawaroh $^{2)}$ Dewi Elliana $^{3)}$ \\ ${ }^{122) 3)}$ Akademi Kebidanan Abdi Husada Semarang \\ Email: srimularsih88@gmail.com
}

\begin{abstract}
ABSTRAK
Jumah penduduk di Indonesia terus bertambah. Perlu adanya suatu upaya untuk mencegah ledakan jumlah penduduk dengan cara Keluarga Berencana (KB). Ada berbagai jenis kontrasepsi, salah satunya alat kontrasepsi dalam rahim (AKDR). Efektifitasnya yang tinggi dapat diandalkan sebagai metode kontrasepsi namun jumlah akseptornya sangat rendah dibandingkan metode lain. Terdapat berbagai faktor yang mempengaruhi antara lain tingkat pengetahuan dan dukungan suami. Kontrasepsi adalah menghindari atau mencegah terjadinya kehamilan sebagai akibat pertemuan sel telur yang matang dengan sel sperma. AKDR adalah suatu benda kecil yang terbuat dari plastik yang lentur, mempunyai lilitan tembaga atau juga mengandung hormon dan dimasukkan ke dalam rahim melalui vagina dan mempunyai benang. Jenis penelitian yang digunakan adalah deskriptif analitik dengan pendekatan cross sectional. Sampel penelitian sebanyak 68 pasangan usia subur, diambil dengan teknik simple random sampling. Analisis bivariat menggunakan uji chi square dengan kemaknaan $p<0$,05. Enam puluh delapan PUS diambil sebagai subjek penelitian dengan memenuhi kriteria inklusi dan eksklusi. Tingkat pengetahuan baik sebanyak 14 responden (20,6\%), sedang 36 responden (52,9\%), buruk 18 responden (26,5\%). Suami yang memberi dukungan sebanyak 49 responden (72,1\%) dan yang tidak mendukung 19 responden $(27,9 \%)$. Responden yang memakai AKDR sebanyak 62 resonden (91,2\%) dan non AKDR 6 respon (8,8\%). Uji bivariat menggunakan uji chi square diperoleh $p$ value $=0,000(p<0,05)$ pada tingkat pengetahuan dan $p=0,175(p>0,05)$ pada dukungan suami Terdapat hubungan bermakna antara tingkat pengetahuan dengan penggunaan AKDR dan tidak terdapat hubungan antara dukungan suami dengan penggunaan AKDR.
\end{abstract}

Kata Kunci : AKDR, tingkat pengetahuan, dukungan suami

ABSTRACT

Population in Indonesia continues to grow. There needs to be an effort to prevent the explosion of population by means of Family Planning (KB). There are different types of contraceptives, one of which is the intrauterine device (IUD). Its high effectiveness can be relied upon as a contraceptive method but the number of acceptors is very low compared to other methods. There are various factors that influence, among others, the level of knowledge and support of the husband. Contraception is to avoid or prevent the occurrence of pregnancy as a result of meeting a mature egg cell with sperm cells. The IUD is a small body made of pliable plastic, has copper windings or also contains hormones and is inserted into the uterus through the vagina and has a thread. The type of research used is descriptive analytic with cross sectional approach. The sample of research is 68 couples of fertile age, taken by simple random sampling technique. Bivariate analysis using chi $\begin{array}{ccccc}\text { square } \quad \text { with } & \text { significance } & <0,05 .\end{array}$ Sixty-eight EFAs were taken as research subjects by meeting inclusion and exclusion criteria. Good knowledge 
level as many as 14 respondents (20,6\%), while 36 respondents (52,9\%), bad 18 respondent (26,5\%). Husband who supported as many as 49 respondents (72.1\%) and who did not support 19 respondents (27.9\%). Respondents using IUDs were 62 resondents (91.2\%) and non-IUD 6 responses (8.8\%). Bivariate test using chi square test obtained $p$ value $=0,000(p<0,05)$ at knowledge level and $p=0,175(p>0,05)$ at husband support There was a significant association between knowledge level and IUD utilization and no relationship between husband support and IUD use.

Keywords: IUD, knowledge level, husband support

\section{PENDAHULUAN}

Indonesia merupakan negara
berkembang dengan
permasalahan kependudukan yang masih
perlu ditangani. Dalam mengatasi
permasalahan kependudukan bangsa
Indonesia mengadakan program
Keluarga Berencana (KB). Untuk mencapai tujuan tersebut, pengelolaan program nasional KB diarahkan pada bentuk sasaran yaitu sasaran langsung berupa pasangan usia subur (PUS), pasangan usia subur 20 - 35 tahun dan sasaran tidak langsung melalui organisasi, lembaga kemasyarakatan, instansi pemerintah maupun swasta, tokoh masyarakat. Program KB bertujuan mewujudkan keluarga kecil yang bahagia dan sejahtera (Hartanto,2004).

Kontrasepsi adalah suatu usaha untuk mencegah untuk terjadinya kehamilan, usaha-usaha itu dapat bersifat sementara dapat juga bersifat permanen. Berbagai macam metode kontasepsi ditawarkan mulai dari metode sederhana seperti metode kalender, kondom, dan metode modern seperti pil, suntik, implant, Intra Uterine Device (IUD), hingga kontrasepsi mantap yaitu Medis Operatif Wanita (MOP) dan Medis Operatif Pria (MOP).

Tujuan gerakan KB lainnya adalah mengatur kehamilan dengan menggunakan alat kontrasepsi. Pemakaian alat kontrasepsi KB yang benar dan tepat oleh WUS dijadikan upaya untuk menunda kehamilan. Itulah sebabnya program pemakaian alat kontrasepsi melalui gerakan $\mathrm{KB}$ di Indonesia secara masal dilakukan sejak tahun 1970-an dan menjadi tumpuan harapan untuk merealisasikan kebijakan kependudukan dalam hal pengendalian jumlah penduduk serta meningkatkan status kesehatan wanita (BKKBN,2009)

Alat kontrasepsi yang mempunyai efektifitas cukup tinggi dan merupakan alat kontrasepsi non hormonal diantaranya AKDR. Alat kontrasepsi dalam rahim (AKDR) merupakan alat konrasepsi yang tidak mengandung hormonal. AKDR terbuat dari nahan plastik yang biasanya mengandung tembaga / hormon steroid dipasang didalam cavum uteri. AKDR yang mengandung tembaga seperti CuT $380 \mathrm{~A}$ terutama bekerja dengan cara mencegah sperma dengan sel telur bertemu, mengurangi jumlah dan aktivitas sperma yang mencapai tuba (Hartanto, 2004). Keuntungan dari dari AKDR ini selain lebih efektif, tidak mempengaruhi kualitas dalam volume ASI bagi ibu yang menyusui, penyulit tidak terlalu berat, dan pulihnya kesuburan setelah pencabutan alat kontrasepsi berlangsung baik, aman, mudah digunakan, karena tidak harus mengingat jadwal suntik atau minum pil KB (Saifudin, 2006).

Seorang wanita mengalami kesulitan didalam menentukan jenis kontrasepsi. Hal ini tidak hanya karena terbatasnya metode yang tersedia tetapi ketidak tahuan PUS tentang persyaratan dan keamanan metode kontrasepsi yang salah satunya adalah AKDR. Berbagai 
faktor harus dipertimbangkan, termasuk status kesehatan, efek samping, konsekuensi kegagalan atau kehamilan yamg tidak diinginkan, besar keluarga yang direncanakan, persetujuan pasangan, bahkan norma budaya lingkungan dan orang tua (Saifudin, 2003).

Banyak suami di Indonesia kurang mendapatkan informasi tentang alat kontrasepsi. Ada beberapa anggapan atau isu yang terjadi di masyarakat diantaranya ketidaknyamanan saat berhubungan, dirasakan mengganggu atau menyebabkan rasa tidak enak, cara pemasangan yang dianggap tabu. Sehingga hal ini menyebabkan rendahnya dukunagn dari suami dalam pemilihan alat kontrasepsi salah satunya adalah AKDR. Suami sebagai kepala rumah tangga dapat berperan dalam pengambilan keputusan inti dalam berKB. Bentuk peran serta tersebut dapat berupa pemberian ijin dan dukungan serta perhatian terhadap KB. Faktor ini menyebabkan AKDR turun dari tahun ke tahun. Penyebab isu ini dikarenakan kurangnya pengetahuan, sikap, dukungan suami, dan konseling yang kurang optimal(Saifudin, 2003).

Data yang didapat dari BKKBN Provinsi Jawa Tengah Tahun 2012 tercatat peserta KB aktif sebanyak 5.43.578 (100\%) akseptor dengan perincian sebagai berikut. Penggunaan suntik sebanyak $3.060 .828 \quad(56,85 \%)$ akseptor, pil $835.365(1,86 \%)$ akseptor, kondom 119.992 (2,24\%) akseptor, IUD 471.560 (8,73\%) akseptor, MOP 57.385 (1,06\%) aseptor, MOW $294.512(5,46 \%)$ akseptor, implan $563.935 \quad(810,44 \%)$ akseptor.

Data yang didapat dari Dinas Kesehatan Kota Semarang tahun 2012 tercatat peserta KB aktif sebanyak $194.423(100,0 \%)$ akseptor dengan perincian sebagai berikut. Pengguna IUD sebanyak $13.191 \quad(6,8 \%)$ akseptor, pil
30.202 (15,5\%) akseptor, kondom 16.200 $(8,3 \%)$ akseptor, suntik $112,910(58,1 \%)$ akseptor, MOP 2.365 (1,2\%) akseptor, MOW 8.614 (4.4\%)akseptor, implant $10.941(5,6 \%)$ akseptor, obat vagina 0 $(0,0 \%)$ akseptor.

Data yang didapat dari DKK DI puskesmas Purwoyoso untuk pengguna $\mathrm{kb}$ IUD masih sedikit dan masyarakat masih banyak menggunakan kontasepsi pil dan suntik di karenakan pengetahuan PUS tentang kontasepsi AKDR masih kurang dan kurangnya dukungan suami sehingga kontrasepsi AKDR menjadi turun.

Berdasarkan data dari Puskesmas Purwoyoso tahun 2012, KB suntik4.618.051(48,2\%)

akseptor,pil2.677.839 (28\%) akseptor, implan768.646 (8,0\%)akseptor,IUD $627.980 \quad(6,5 \%)$ akseptor,MOP dan MOW140.637 (1,5\%) akseptor, Hal ini menunjukkan pengguna KB IUD sangat sedikit dibandingkan dengan kontrasepsi lain (Laporan Pelayanan KB Puskesmas Purwoyoso, 2012). Puskesmas Purwoyoso membawahi 2 kelurahan yaitu keluraha Purwoyodo dan kelurahan Kalipancur.

Berdasarkan data dari Kelurahan Kalipancur tercatat peserta KB aktif sebanyak 1929 akseptor dengan perincian sebagai berikut KB suntik $60,17 \%$ akseptor, pil 3,3\% akseptor, implan $0,19 \%$ akseptor, IUD $0.19 \%$ akseptor, MOP dan MOW 1,3\% akseptor, kondom $0 \%$ akseptor ( Laporan Pelayanan KB di Kelurahan Kalipancur, 2013).

Di Kelurahan Purwoyoso terdiri dari 14 RW 99 RT dengan jumlah PUS 2962 tercatat peserta KB aktif sebanyak 2270 akseptor dengan perincian sebagai berikut KB suntik $72,2 \%$ akseptor, pil $4,3 \%$ akseptor, implan 2,3\% akseptor, IUD 2.8\% akseptor, MOP dan MOW $2,3 \%$ akseptor, kondom $0.4 \%$ akseptor ( 
Laporan Pelayanan KB di Kelurahan Purwoyoso, 2013).

Studi pendahuluan yang dilakukan pada bulan November 2013 di Kelurahan Purwoyoso Kercamatan Ngaliyan pada 10 akseptor KB, diantaranya 2 PUS (20\%) memilih kontasepsi AKDR, 8 PUS (80\%) tidak memilih kontrasepsi AKDR. Diketahui bahwa pemilihan AKDR sangat sedikit dikarenakan masyarakat masih takut akan AKDR karena AKDR dimasukkan lewat jalan lahir. Sehingga mayoritas mempunyai anggapan pemakaian alat kontrasepsi hormonal (pil, suntik) lebih baik dari pada non hormonal (AKDR). Hal ini dikarenakan pengetahuan suami tentang kontrasepsi AKDR kurang, dan kurangnya dukungan suami. Sehingga menyebabkan pemilihan kontrasepsi AKDR turun.

Berdasarkan hasil tersebut, peneliti tertarik mengambil judul penelitian "Hubungan Pengetahuan dan Dukungan Suami dengan Pemilihan Kontrasepsi AKDR pada PUS di Kelurahan Purwoyoso Kecamatan Ngalian Semarang".

\section{METODE PENELITIAN}

Penelitian ini menggunakan rancangan cross sectional yaitu rancangan penelitian yang dalam melakukan pengukuran variabel independen (pengetahuan dan dukungan suami) dan variabel dependen (pemilihan alat kontrasepsi AKDR) dalam periode yang sama. Penelitian ini termasuk jenis penelitian survey analitik yaitu penelitian yang menggunakan sampel untuk mengambil kesimpulan pada populasi. Populasi dalam penelitianadalah semua PUS yang menjadi akseptor KB yang tercatat di Kelurahan Purwoyoso sebanyak 209 dan sampel yang didapat sejumlah 68 .

\section{HASIL PENELITIAN}

\section{Analisis Univariat}

a. Tingkat pendidikan responden

Tabel 1. Distribusi frekuensi responden berdasar tingkat pendidikan

\begin{tabular}{ccc}
\hline $\begin{array}{c}\text { Tingkat } \\
\text { pendidikan }\end{array}$ & Jumlah (n) & Prosentase (\%) \\
\hline SD & 24 & 35,3 \\
SMP & 29 & 42,6 \\
SMA & 15 & 22,1 \\
\hline Total & 68 & 100 \\
\hline
\end{tabular}

Tingkat pendidikan terbanyak responden adalah SMP dengan jumlah 29 orang $(42,6 \%)$ sedangkan yang paling sedikit adalah SMA yaitu sebanyak 15 orang $(22,1 \%)$.

\section{b. Tingkat pengetahuan responden}

Tabel 2. Distribusi frekuensi responden berdasar tingkat pengetahuan

\begin{tabular}{ccc}
\hline $\begin{array}{c}\text { Tingkat } \\
\text { Pengetahuan }\end{array}$ & Frekuensi (n) & Persentase (\%) \\
\hline Baik & 14 & 20,6 \\
Sedang & 36 & 52,9 \\
Buruk & 18 & 26,5 \\
\hline Total & 68 & 100 \\
\hline
\end{tabular}

Tingkat pengetahuan ibu PUS mengenai kontrasepsi AKDR terbanyak adalah tingkat pengetahuan sedang yaitu 36 orang $(52,9 \%)$ dan paling sedikit adalah tingkat pengetahuan baik sebanyak 14 orang $(20,6 \%)$.

\section{c. Dukungan suami}

Tabel 3. Distribusi frekuensi responden berdasar dukungan suami 


\begin{tabular}{ccc}
\hline $\begin{array}{c}\text { Dukungan } \\
\text { suami }\end{array}$ & Frekuensi (n) & $\begin{array}{c}\text { Persentase } \\
\text { (\%) }\end{array}$ \\
\hline Mendukung & 49 & 72,1 \\
Tidak & 19 & 27,9 \\
Mendukung & & \\
\hline Total & 68 & 100 \\
\hline
\end{tabular}

Dari tabel di atas dapat diketahui bahwa sebanyak 49 orang $(72,1 \%)$ responden didukung oleh suaminya untuk menggunakan kontrasepsi AKDR.

\section{d. Pemilihan Alat Kontrasepsi}

Tabel 4. Distribusi frekuensi berdasar pemilihan alat kontrasepsi

\begin{tabular}{ccc}
\hline $\begin{array}{c}\text { Pemilihan } \\
\text { kontrasepsi }\end{array}$ & $\begin{array}{c}\text { Frekuensi } \\
\text { (n) }\end{array}$ & Persentase (\%) \\
\hline Non AKDR & 62 & 91,2 \\
AKDR & 6 & 8,8 \\
\hline Total & 68 & 100 \\
\hline
\end{tabular}

Responden yang memilih Non

AKDR adalah sebanyak 62 orang $(91,2)$ dibanding yang memilih AKDR yaitu 6 orang $(8,8 \%)$

\section{Analisis Bivariat}

Pengambilan data pada penelitian ini dilakukan dengan menggunakan kuisioner dengan 15 pertanyaan untuk tingkat pengetahuan ibu PUS dan 17 pertanyaan untuk menilai dukungan suami. Berdasarkan data hasil penelitian, dilakukan tabulasi silang hubungan tingkat pengetahuan ibu PUS dengan pemilihan menggunakan kontrasepsi AKDR yang dilakukan terhadap 68 responden, diperoleh hasil sebagai berikut :

Tabel 5. Hubungan antara tingkat pengetahuan ibu PUS tentang kontrasepsi AKDR dengan pemilihan penggunaan kontrasepsi AKDR

\begin{tabular}{|c|c|c|c|c|}
\hline \multirow[b]{2}{*}{ Pengetahuan } & \multicolumn{2}{|c|}{ Pemilihan kontrasepsi } & \multirow[b]{2}{*}{ Jumlah\% } & \multirow[b]{2}{*}{$\mathrm{p}$} \\
\hline & $\begin{array}{c}\text { Non } \\
\text { AKDR\% }\end{array}$ & AKDR\% & & \\
\hline Baik & $8(57,1)$ & $\begin{array}{r}6 \\
(42,9)\end{array}$ & $14(20,6)$ & 0,000 \\
\hline Cukup & $36(100)$ & $0(0)$ & $36(52,9)$ & \\
\hline Kurang & $18(100)$ & $0(0)$ & $18(26,5)$ & \\
\hline $\mathrm{J} \mathrm{u} \mathrm{m} \mathrm{lah}$ & $62(91,2)$ & $6(8,8)$ & $68(100)$ & \\
\hline
\end{tabular}

Dari Tabel 5 Hubungan antara tingkat pengetahuan ibu PUS tentang kontrasepsi AKDR dengan pemilihan penggunaan kontrasepsi AKDR di peroleh hasil bahwa pengetahuan responden dengan kategori baik sebanyak 14 responden $(20,6 \%)$ dengan perincian non AKDR 8 responden (57,1\%), AKDR 6 responden (42,9\%). Pengetahuan dengan kategori cukup pemilihan non AKDR sebanyak 36 responden (52,9\%), Pengetahuan dengan kategori kurang pemilihan non AKDR sebanyak 18 responden (100\%).

Data penelitian yang didapat dilakukan analisis bivariat dengan menggunakan program SPSS versi 16.0. Digunakan uji Chi square dengan prinsip tabel $2 \times \mathrm{K}$ untuk menilai hubungan antara tingkat pengetahuan ibu PUS dengan pemilihan penggunaan kontrasepsi AKDR. Dari hasil analisis didapatkan adanya 3 sel $(50 \%)$ yang memiliki expected count $<5$ dan terdapat sel yang kosong. Hal ini menyebabkan hasil uji Chi square tidak dapat diinterpretasi karena tidak memenuhi syarat. Syarat uji chi square yaitu expected count $<5$ maksimal 20 $\%$ dari total sel. Kondisi ini menharuskan kita untuk menggunakan uji alternatif yaitu Kolmogorov Smirnov sebagai alternatif uji Chi square tabel 2 $\mathrm{x}$ K. Hasil uji didapatkan hasil $\mathrm{p}=$ $0,000(\mathrm{p}<0,05)$ yang memiliki arti "ada hubungan antara tingkat pengetahuan ibu PUS tentang kontrasepsi AKDR dengan pemilihan kontrasepsi AKDR di 
Kelurahan Purwoyoso Ngaliyan

Semarang.

Data dukungan suami juga dianalisis dengan cara yang sama seperti di atas dengan menggunakan uji Chi square. Berdasarkan data hasil penelitian, dilakukan tabulasi silang hubungan dukungan suami dengan pemilihan menggunakan kontrasepsi AKDR yang dilakukan terhadap 68 responden, diperoleh hasil sebagai berikut :

Tabel 6. Hubungan antara dukungan suami dengan pemilihan penggunaan kontrasepsi AKDR

\begin{tabular}{lcccc}
\hline \multirow{3}{*}{ Pengetahuan } & \multicolumn{2}{c}{$\begin{array}{c}\text { Pemilihan } \\
\text { kontrasepsi }\end{array}$} & Jumlah\% & p \\
\cline { 2 - 3 } & $\begin{array}{c}\text { Non } \\
\text { AKDR\% }\end{array}$ & $\begin{array}{c}\text { AKDR } \\
\%\end{array}$ & & \\
\hline Mendukung & $43(87,7)$ & $\begin{array}{c}6 \\
(12,3)\end{array}$ & $49(72,0)$ & 0,17 \\
Tidak & $19(100)$ & $0(0)$ & $19(28,0)$ & 5 \\
mendukung & & & & \\
\hline J u m la h & $62(91,2)$ & $6(8,8)$ & $68(100)$ & \\
\hline
\end{tabular}

Dari Tabel 6 Hubungan antara dukungan suami dengan pemilihan penggunaan kontrasepsi di peroleh hasil bahwa pengetahuan responden dengan kategori mendukung sebanyak 49 responden $(20,6 \%)$ dengan perincian non AKDR 48 responden $(87,7 \%)$, AKDR 6 responden (12,3\%). Pengetahuan dengan kategori tidak mendukung pemilihan non AKDR sebanyak 19 responden $(100 \%)$.

Data penelitian yang didapat dilakukan analisis bivariat dengan menggunakan program SPSS versi 16.0. Digunakan uji Chi square dengan prinsip tabel $2 \times 2$ untuk menilai hubungan antara dukungan suami dengan pemilihan penggunaan kontrasepsi AKDR. Dari hasil analisis didapatkan adanya 2 sel $(50 \%)$ yang memiliki expected count $<$ 5 dan terdapat sel yang kosong. Hal ini menyebabkan hasil uji Chi square tidak dapat diinterpretasi karena tidak memenuhi syarat. Syarat uji chi square yaitu expected count $<5$ maksimal $20 \%$ dari total sel. Kondisi ini menharuskan kita untuk menggunakan uji alternatif yaitu Fisher exact sebagai alternatif uji Chi square tabel $2 \times 2$. Hasil uji didapatkan hasil $\mathrm{p}=0,175(\mathrm{p}>0,05)$ yang memiliki arti "tidak ada hubungan antara dukungan suami dengan pemilihan kontrasepsi AKDR di Kelurahan Purwoyoso Ngaliyan Semarang.

\section{PEMBAHASAN}

\section{Tingkat Pengetahuan ibu PUS tentang AKDR}

Hasil dekripsi univariat diperoleh hasil sebagian besar responden memiliki tingkat pengetahuan yang cukup yaitu sebanyak 36 responden $(52,9 \%)$ dan kurang sebanyak 18 responden (26,5\%). Menurut Mubarok (2007), tingkat pengetahuan seseorang dipengaruhi oleh tingkat pendidikannya. Pendidikan adalah bimbingan yang diberikan seseorang pada orang lain terhadap sesuatu hal agar mereka dapat memahaminya. Makin tinggi pendidikan seseorang semakin mudah pula mereka menerima informasi, dan pada akhirnya makin banyak pula pengetahuan yang dimilikinya. Sebaliknya jika seseorang tingkat pendidikannya rendah, akan menghambat perkembangan sikap seseorang terhadap penerimaan, informasi dan nilai - nilai yang baru diperkenalkan.

Pengetahuan yang baik terhadap suatu hal tidak terjadi dalam waktu yang singkat melainkan melalui suatu proses tertentu. Menurut Notoatmodjo (2005), pengetahuan harus melalui 6 tahapan yaitu tahu, memahami, aplikasi, analisis, sintesis dan evaluasi. Masingmasing tahapan memiliki peranan dalam menentukan tingkat pengetahuan seseorang.

Pengetahuan ibu PUS tentang kontrasepsi AKDR sebanding dengan tingkat pendidikan mereka yang juga 
rendah. Sebanyak 24 responden $(35,3 \%)$ hanya berpendidikan SD dan 29 responden $(42,6 \%)$ berpendidikan SMP. Dengan hanya berpendidikan SD dan SMP, responden agak sulit untuk menerima informasi yang disampaikan berkaitan dengan kontrasepsi AKDR. Selain itu, ada keterbatasan kemampuan akses terhadap sumber-sumber informasi yang saat ini ada. Seharusnya dengan dukungan media massa yang ada khususnya internet, semua informasi yang menjelaskan tentang kontrasepsi AKDR sangat banyak tersedia dan dapat diakses dimanapun dan kapanpun. Namun karena keterbatasan kemampuan yang dimiliki oleh responden itulah sehingga sumber informasi yang sangat banyak tidak dapat dimanfaatkan dengan baik.

\section{Dukungan Suami}

Hasil dekripsi univariat diperoleh hasil sebagian besar responden mendukung istrinya untuk menggunakan kontrasepsi AKDR. Tercatat 49 responden $(72,1 \%)$ memberikan dukungan kepada istrinya untuk menggunakan kontrasepsi AKDR.

Dukungan suami adalah dukungan yang diberikan oleh suami dalam bentuk verbal dan non verbal, saran, bantuan yang nyata berupa tingkah laku atau kehadiran yang dapat memberikan keuntungan emosional dan mempengaruhi tingkah laku istrinya.

Menurut Friedman (1998), ada 4 dukungan yang dapat diberikan suami kepada istrinya yaitu dukungan emosional, dukungan penghargaan atau penilaian, dukungan Instrumental dan dukungan infomatif. Dukungan suami dapat diterjemahkan sebagai sikap penuh pengertian yang ditunjukkan dalam bentuk kerja sama yang positif, ikut membantu menyelesaikan pekerjaan rumah tangga, serta memberikan dukungan moral dan emosional terhadap karir atau pekerjaan istrinya.

Tanggung jawab pria / suami dalam keterlibatan dan keikutsertaan ber-KB, serta perilaku seksual yang sehat dan aman bagi dirinya, pasangannya dan keluarganya. Bentuk partisipasi pria / suami dalam ber-KB dapat dilakukan secara langsung maupun tidak langsung (BKKBN, 2003).

\section{Kontrasepsi AKDR}

Berdasarkan hasil penelitian didapatkan hasil sebanyak 62 responden $(91,2 \%)$ memakai kontrasepsi NonAKDR dan hanya 6 responden $(8,8 \%)$ yang memakai AKDR.

Menurut Handayani (2010), AKDR adalah suatu benda kecil yang terbuat dari plastik yang lentur, mempunyai lilitan tembaga atau juga mengandung hormon dan dimasukkan ke dalam rahim melalui vagina dan mempunyai benang.

Rendahnya ibu PUS yang menggunakan kontrasepsi AKDR tidak terlepas dari rendahnya pengetahuan ibu PUS tentang kontrasepsi AKDR. Penggunaan kontrasepsi metode AKDR akan lebih banyak apabila banyak PUS yang memiliki pengetahuan yang baik tentang definisi AKDR, mekanisme kerja, indikasi, keuntungan, efek samping dan kontra indikasinya. Tanpa pengetahuan tersebut, maka kesadaran akseptor KB untuk memilih menggunakan kontrasepsi AKDR akan sangat rendah (Notoatmodjo, 2005).

\section{Hubungan antara tingkat pengetahuan ibu PUS tentang kontrasepsi AKDR dengan pemilihan kontrasepsi AKDR}

Berdasarkan hasil analisis data penelititan menggunakan uji bivariat chi square yang dilanjutkan dengan uji 
Kolmogorov Smirnov, diperoleh hasil bahwa ada hubungan yang bermakna antara tingkat pengetahuan ibu PUS tentang kontrasepsi AKDR dengan pemilihan kontrasepsi AKDR, dengan nilai $\mathrm{p}=0,000$. Hasil tersebut berarti nila $\mathrm{p}<0,05$ sehingga Ha diterima.

Menurut Notoatmodjo (2005), pengetahuan merupakan hasil dari tahu, dan ini terjadi setelah orang melakukan penginderaan suatu obyek tertentu. Pengetahuan dipengaruhi oleh beberapa faktor antara lain: sosial ekonomi, kultur (budaya, agama), pendidikan, pengalaman, perilaku adalah segala tingkah laku yang didorong kemauan seseorang.

Tingkat pengetahuan ibu PUS tentang kontrasepsi AKDR diperoleh pengetahuan yang baik 14 responden (20,6\%), pengetahuan cukup 36 responden $(52,9 \%)$ dan pengetahuan kurang 18 responden $(26,5 \%)$. Hal ini sesuai dengan teori Mubarok (2007) yang menyatakan salah satu faktor yang mempengaruhi pengetahuan adalah tingkat pendidikan. Makin tinggi pendidikan seseorang semakin mudah pula mereka menerima informasi, dan pada akhirnya makin banyak pula pengetahuan yang dimilikinya. Sebaliknya jika tingkat pendidikannya rendah, akan menghambat perkembangan sikap seseorang terhadap penerimaan, informasi dan nilai-nilai yang baru diperkenalkan. Hasil penelitian ini didapatkan 52,9 \% responden memiliki pengetahuan yang cukup dan 26,5 \% memiliki pengetahuan kurang. Hal ini terkait dengan pendidikan masyarakat yang mayoritas lulus SD dan SMP yang masih sangat terbatas dalam melakukan eksplorasi terhadap sumber-sumber informasi yang benar tentang kontrasepsi AKDR. Banyak masyarakat yang tidak mampu menjangkau sumber informasi yang banyak tersedia di pusat layanan kesehatan. Kesadaran untuk menambah pengetahuan melalui bukubuku dan internet juga masih rendah. Justru sebaliknya banyak masyarakat hanya menggunakan internet sebagai sarana pertemanan melalui jejaring sosial daripada mencari sumber informasi yang dapat memperluas wawasannya terhadap sesuatu ilmu yang mungkin belum pernah diperoleh selama sekolah.

Distribusi frekuensi penggunaan AKDR hanya diperoleh 6 responden $(8,8 \%)$. Sisanya sebanyak 62 responden (91,2 \%) tidak menggunakan AKDR. Banyaknya ibu PUS yang tidak menggunakan AKDR dikarenakan oleh beberapa alasan. Alasan utama responden yang tidak menggunakan AKDR adalah karena sebagian besar tidak mengetahui kelebihan penggunaan kontrasepsi AKDR. Hal ini ditunjukkan dari kemampuan responden dalam memberikan jawaban pada kuisioner yang dibagikan peneliti.

Rendahnya pengetahuan masyarakat tentang alat kontrasepsi AKDR dan berbagai anggapan yang salah tentang metode AKDR antara lain bahwa pemasangan AKDR memerlukan biaya yang mahal, dapat menimbulkan ketidak nyamanan saat berhubungan seksual, dan AKDR merupakan suatu hal yang menakutkan karena memasukkan benda asing kedalam alat genitalianya menyebabkan keikutsertaan akseptor yang menggunakan AKDR masih rendah. Memang ada pula beberapa lapisan masyarakat yang lebih maju dan menilai bahwa AKDR lebih unggul dari alat kontrasepsi yang lainnya karena praktis (hanya melakukan satu kali pemasangan), tidak perlu sering kontrol dan efektifitas yang tinggi (Wiknjosastro, 2005).

Hasil penelitian ini sesuai dengan penelitian sebelumnya yang dilakukan 
oleh Siti Widiyawati dkk (2012) dengan judul "Faktor-faktor Yang Berhubungan Dengan Pemakaian AKDR Di Wilayah Kerja Puskesmas Batuah Kutai Kartanegara" yang memperoleh hasil adanya hubungan bermakna antara pengetahuan dengan pengguanaan AKDR dengan nilai $\mathrm{p}=0,007(\mathrm{p}<$ 0,05).

Penelitian lain dari Yuda Yulia Kristiarini (2010) dengan judul "Hubungan Antara Tingkat Pengetahuan Dan Motivasi Ibu Peserta Keluarga Berencana Dengan Persepsi Kesuburan Setelah Melahirkan Di Puskesmas Klaten Utara" juga menemukan hasil yang serupa dengan penelitian ini yaitu $\mathrm{p}=0,000(\mathrm{p}<0,05)$ yang berarti terdapat hubungan antara pengetahuan dengan peran serta $\mathrm{KB}$ khususnya penggunaan AKDR.

PUS yang memiliki pengetahuan yang tinggi cenderung memilih memakai alat kontrasepsi AKDR karena mereka menganggap bahwa efek samping AKDR merupakan suatu hal yang wajar. Sebaliknya PUS yang memiliki pengetahuan rendah cenderung untuk tidak memilih alat kontrasepsi AKDR, dikarenakan mereka menganggap efek samping AKDR merupakan suatu hal yang menakutkan

\section{Hubungan antara tingkat pengetahuan ibu PUS tentang kontrasepsi AKDR dengan pemilihan kontrasepsi AKDR}

Pada penelitian ini ditemukan hasil bahwa tidak terdapat hubungan antara dukungan suami dengan pemilihan penggunaan kontrasepsi AKDR dengan nilai $\mathrm{p}=0,175(\mathrm{p}>$ $0,05)$

Hasil penelitian ini sesuai dengan penelitian sebelumnya yang dilakukan oleh Imas Sugiarti dkk (2012). Dalam penelitiannya dengan judul "Faktor Pasangan Yang Mempengaruhi
Pemilihan Jenis Kontrasepsi Pada Wanita Usia Subur; Studi di Kelurahan Cipari Kota Tasikmalaya" ditemukan hasil tidak ada hubungan antara dukungan suami dengan pemilihan jenis kontrasepsi pada WUS dengan nilai $\mathrm{p}=$ $0,939(\mathrm{p}>0,05)$.

Penelitian lain menurut Johana D. Bernardus dkk (2013) dengan judul "Faktor-faktor Yang Berhubungan Dengan Pemilihan AKDR Bagi Akseptor KB di Jailolo" menemukan hasil serupa yaitu tidak terdapat hubungan dukungan suami dengan pemilihan kontrasepsi AKDR dengan nilai $\mathrm{p}=0,356(\mathrm{p}>0,05)$.

Dukungan suami hanya merupakan salah satu faktor penguat (reinforcing) yang dapat mempengaruhi seorang ibu PUS untuk menentukan sikapnya. Dukungan suami dalam KB merupakan bentuk nyata kepedulian dan tanggung jawab pria dalam berpartisipasi.

Menurut Notoatmodjo (2005), perilaku seseorang dipengaruhi oleh 3 faktor yaitu faktor predisposing, faktor enabling, dan faktor reinforcing. Keputusan untuk memilih menggunakan kontrasepsi AKDR tidak bisa hanya dipengaruhi oleh dukungan suami saja, namun banyak faktor lain yang menyebabkan ibu PUS memilih tidak menggunakan kontrasepsi AKDR yang tidak diteliti dalam penelitian ini.

\section{SIMPULAN}

1. Tingkat pengetahuan ibu PUS yang baik sebanyak 14 orang $(20,6 \%)$, sedang 36 orang $(52,9 \%)$ dan kurang 18 orang $(26,5 \%)$

2. Dukungan suami yang mendukung menggunakan AKDR sebanyak 49 orang $(71,2 \%)$ dan tidak mendukung sebanyak 19 orang $(27,9 \%)$ 
3. Ibu PUS yang menggunakan kontrasepsi non-AKDR sebanyak 62 orang $(91,2 \%)$ dan yang menggunakan AKDR 6 orang $(8,8 \%)$

4. Ada hubungan yang bermakna antara tingkat pengetahuan ibu PUS tentang AKDR dengan pemilihan penggunaan kontrasepsi AKDR dengan angka signifikansi $p=0,000(p<0,05)$

5. Tidak ada hubungan antara dukungan suami dengan pemilihan penggunaan kontrasepsi AKDR dengan angka $p=$ $0,175(\mathrm{p}>0,05)$

\section{DAFTAR PUSTAKA}

Arikunto S. 2006. Prosedur Penelitian : Suatu Pendekatan Praktek. Jakarta, Rineka Cipta

BKKBN. 2003. Peran Pria melalui Program KB dalam Kesehatan Maternal. Gema Partisipasi Pria. Jakarta

-----------. 2010. Cara - cara Kontrasepsi yang digunakan dewasa ini. Diperoleh dari: http://www.bkkbnjatim.go.id/bkkbn-jatim/html/cara.htm

------ (a). 2011. Penduduk Indonesia 241 Juta Jiwa.Downloaded 05 Oktober 2012. Available from: www.republika.co.id > Nasional (b). 2011. Hasil pelaksanaan Sub Sistem Pencatatan Pelaporan Pelayanan Kontrasepsi. Downloaded 12 Oktober 2012. Available from: http://www.bkkbn.go.id/arsip/Default.as $\mathrm{px}$

Handayani S. 2010. Buku Ajar Keluarga Berencana. Yogyakarta

Hartanto. 2003. Keluarga Berencana dan Kontrasepsi. CV. Mulia. Jakarta

Hartanto H. 2004. Keluarga Berencana dan Kontrasepsi. Pustaka Sinar Harapan. Jakarta

Hidayat AA. 2007. Metode Penelitian Keperawatan dan Teknik Analisis Data. Jakarta: Salemba Medika
Kuntjoro, Z. 2002. DukungamsosialpadaLansia.http:/www .E-psikologi.com/diunduh 10 november 2010

Laporan Pelayanan Keluarga Berencana Puskesmas Purwoyoso tahun 2012

Mansjoer A. 2002. Kapita Selekta Kedokteran.Edisi 2. Jakarta : Media Aesculapius, FKUI

Manuaba IB. 2010. Ilmu Kebidanan, Penyakit Kandungan, dan KB. Jakarta : EGC

Mubarok. 2007. Promosi Kesehatan Sebuah Pengantar Proses Belajar Mengajar Dalam Pendidikan. Yogyakarta: Graha Ilmu.

Notoatmodjo S. 2005. Promosi Kesehatan: Teori dan Aplikasi. Jakarta: Rineka Cipta

---------. 2010. Metodologi Penelitian Kesehatan. Jakarta : Rineka Cipta

Noviawati D, Sujiyatini S. 2011. Panduan Lengkap Pelayanan KB Terkini. Yogyakarta : Nuha Medika

Nursalam. 2008. Konsep dan Penerapan Metodologi Penelitian Ilmu Keperawatan. Salemba Medika. Jakarta

Pinem S. 2009. Kesehatan Reproduksi dan Kontrasepsi. Jakarta : Trans Info Media.

Profil Kesehatan Jawa Tengah 2012. Diakses dari : http://www.depkes.go.id 06 Januari 2014

Saifudin. 2006. Buku Panduan Praktis Pelayanan Kontrasepsi. Jakarta : Yayasan Bina Pustaka Sarwono Prawirohardjo

Setiadi. 2007. Konsep dan Penulisan Riset Keperawatan. Yogyakarta: Graha Ilmu

Soemarto H. 2003. Inovasi Partisipasi dan Good Governance. Yayasan Obor Indonesia. Jakarta

Sofyan M. 2006. 50 tahun Ikatan Bidan Indonesia: Bidan Menyongsong Masa Depan. Jakarta : PP IBI

Sopiyudin D. 2011. Statistik Untuk Kedokteran dan Kesehatan. Jakarta : Salemba Medika 
Sugiyono. 2007. Statistik untuk Penelitian. Bandung : Alfabeta

Sulistyawati A. 2011. Pelayanan Keluarga Berencana. Jakarta : Salemba Medika

Winkjosastro H. 2005. Ilmu Kebidanan. Edisi ke-3. Jakarta : Yayasan Bina Pustaka Sarwono Prawirohardjo 